\begin{tabular}{|c|c|c|}
\hline & $\begin{array}{c}\text { Bioeduca: Journal of Biology Education } \\
\text { http://journal.walisongo.ac.id/index.php/bioeduca } \\
\text { ISSN 2086-9324 (print) }\end{array}$ & BíOEDUTCA \\
\hline WALISONGO & $\begin{array}{c}\text { Volume 1, Nomor 1, Tahun } 2019 \\
\text { Hal. } 18-28\end{array}$ & \\
\hline
\end{tabular}

\title{
Pengembangan Modul Biologi Bernilai Islam Materi Sistem Reproduksi pada Manusia
}

\author{
Ana Maulidatul Hasanah ${ }^{1^{*}}$, Ismail ${ }^{2}$, Siti Mukhlishoh Setyawati ${ }^{3}$ \\ 1, 2,3Pendidikan Biologi, Universitas Islam Negeri Walisongo Semarang \\ *Email: idamaulida20@gmail.com
}

\begin{tabular}{|c|c|}
\hline Informasi Artikel & ABSTRAK \\
\hline $\begin{array}{l}\text { Submit: } 10-08-2019 \\
\text { Diterima: } 12-08-2019 \\
\text { Dipublikasikan: } 31-09-2019\end{array}$ & $\begin{array}{l}\text { Pengembangan modul biologi bernilai Islam ini bertujuan untuk } \\
\text { menghasilkan sumber belajar Biologi dilengkapi dengan nilai } \\
\text { Islam. Penelitian ini merupakan penelitian pengembangan } \\
\text { dengan memodifikasi pola 4D (Define, Design, Develop and } \\
\text { Disseminate). Tahap define guna menyiapkan kebutuhan dalam } \\
\text { pengembangan modul. Tahap selanjutnya adalah design guna } \\
\text { merancang modul yang dikembangkan. Pengembangan } \\
\text { dilanjutkan dengan tahap develop yang mana pada tahap ini ada } \\
3 \text { macam jenis penilaian yang dilakukan untuk mengetahui } \\
\text { tingkat kelayakan modul yang dikembangkan. Penelitian ini telah } \\
\text { menghasilkan prototype modul Biologi bernilai Islam dengan } \\
\text { kualitas layak dan siap untuk diuji cobakan pada tahap } \\
\text { berikutnya, yaitu disseminate. Modul yang dikembangkan masuk } \\
\text { dalam kategori layak untuk digunakan karena, persentase rata- } \\
\text { rata penilaian dari ahli materi } 81.9 \% \text {, untuk ahli media } 83.3 \% \text { dan } \\
\text { guru biologi } 82 \% \text {. Hasil untuk presentase tanggapan peserta } \\
\text { didik pada kelas kecil adalah } 78 \% \text { dengan kriteria layak, dan } \\
\text { tanggapan peserta didik pada kelas besar sebesar } 80,64 \% \\
\text { dengan kriteria layak. } \\
\text { Kata Kunci: biologi; bernilai islam; modul; sistem reproduksi. }\end{array}$ \\
\hline Penerbit & ABSTRACT \\
\hline $\begin{array}{l}\text { Program Studi Pendidikan } \\
\text { Biologi, Fakultas Sains dan } \\
\text { Teknologi, UIN Walisongo } \\
\text { Semarang }\end{array}$ & $\begin{array}{l}\text { The development of Islamic Biology module aims to produce } \\
\text { Biology learning resources equipped with Islamic values. This } \\
\text { research is a development research by modifying the pattern of } \\
4 D \text { The define stage has been performed as a preliminary study, } \\
\text { various analyzes were performed at the define stage in order to } \\
\text { prepare the needs in module development. The next stage is } \\
\text { design to design the modules developed. Development is } \\
\text { continued with the development stage which at this stage there } \\
\text { are } 3 \text { kinds of assessment conducted to determine the level of } \\
\text { eligibility module developed. This research has resulted in } \\
\text { prototype of Islamic Biology module with decent quality and ready } \\
\text { to be tested at the next stage, that is disseminate. The developed } \\
\text { modules fall into the category worthy of use because, the average } \\
\text { percentage of assessment from the material experts is } 81.9 \% \text {, for } \\
\text { the } 83.3 \% \text { media expert and } 82 \% \text { biology teacher. Results for } \\
\text { percentage of students 'responses in small classes were } 78 \% \\
\text { with eligible criteria, and students' responses to large classes } \\
\text { were } 80.64 \% \text { with eligible criteria. } \\
\text { Keywords: biology; islamic values; module; reproductive system. }\end{array}$ \\
\hline
\end{tabular}

Copyright ( 2019 , Bioeduca: Journal of Biology Education 


\section{PENDAHULUAN}

Pendidikan bertujuan membangun landasan bagi perkembangan potensi peserta didik agar menjadi manusia yang beriman dan bertakwa kepada Tuhan Yang Maha Esa, berakhlak mulia, berkepribadian luhur, berilmu, cakap, kritis, kreatif, inovatif, mandiri, dan percaya diri, toleran, serta bertanggung jawab. Hal tersebut sesuai dengan Peraturan Pemerintah Nomor 17 tahun 2010 tentang Pengelolaan dan Penyelenggaraan Pendidikan. Guna mencapai tujuan tersebut diperlukan usaha yang yang berkesinambungan termasuk di dalamnya ialah penyelenggaraan pendidikan biologi di Madrasah Aliyah (MA). Salah satu usaha yang bisa dilakukan ialah dengan mengintegrasikan pendidikan biologi di MA dengan nilai-nilai keislaman.

Al-Qur'an tidak membedakan antara ilmu-ilmu agama (Islam) dan ilmu-ilmu umum (sains teknologi dan sosial humaniora), baik ilmu agama maupun ilmu umum tidak bisa dipisahkan satu sama lain. Hakikatnya, semua ilmu datang dari Allah SWT. Biologi pada dasarnya merupakan ilmu pengetahuan yang mempelajari tentang makhluk hidup, tetapi biologi tidak bisa dipisahkan dengan ilmu agama. Sebagai buktinya, banyak sekali ayat-ayat Al-Qur'an yang Allah firmankan dan mempunyai kaitan dengan biologi.

Salah satu materi biologi yang banyak kaitannya dengan Nilai Islam adalah, sistem reproduksi pada manusia. Pendidikan sistem reproduksi sejak dini perlu diberikan kepada para remaja (siswa SMA/MA) karena pada masa tersebut, pengetahuan akan sistem reproduksi mereka sedang berada pada puncaknya, tak jarang potensi tersebut disalahgunakan apabila pendidikan tersebut tidak dibarengi dengan bekal ilmu agama. Pengintegrasian materi sistem reproduksi dengan nilai Islam dirasa akan menjadi suatu hal yang sangat tepat apabila diterapkan dalam kegiatan pembelajaran di MA.

Proses untuk memperoleh ilmu akan berjalan secara efektif dan efisien jika tersedia sumber belajar yang berkualitas dan mendukung. Sumber belajar adalah segala macam sumber yang ada di luar diri seseorang dan memungkinkan terjadinya proses belajar mengajar (Rohani, 1997). Modul merupakan salah satu bentuk inovasi sumber belajar yang dapat dipakai dalam proses belajar mengajar.

Modul adalah sebuah buku yang ditulis dengan tujuan agar peserta didik dapat belajar secara mandiri tanpa atau dengan bimbingan guru. (Prastowo, 2012). Modul bernilai Islam dirasa akan menjadi salah satu pilihan sumber belajar yang tepat bagi peserta didik pada masa sekarang ini, dikarenakan akan membantu peserta didik dalam mempelajari materi yang diinginkan dan tentunya materi tersebut akan dikuatkan dengan dalil Al-Qur'an maupun Hadits yang berkaitan dengan materi yang dipelajari. Hal inilah yang mendorong peneliti untuk melakukan penelitian dengan judul "Pengembangan Modul Biologi Bernilai Islam Materi Sistem Reproduksi pada Manusia Kelas XI MA".

\section{METODE PENELITIAN}

Jenis penelitian ini adalah Research and Development $(R \& D)$. Model yang digunakan dalam penelitian ini adalah model 4D. Model ini terdiri dari 4 tahap pengembangan, yaitu Define (pendefinisian), Design (Perancangan), Develop (pengembangan), dan Disseminate (penyebaran) (Trianto, 2010). Instrumen yang digunakan berupa tes (pre-test dan post-test) serta lembar angket check list. Data 
yang diperoleh, selanjutnya dianalisis secara kuantitatif untuk insrumen tes dan kualitatif untuk instrumen angket.

Tahap define dimulai dengan melakukan berbagai analisis guna mencari tahu kebutuhan-kebutuhan dalam pengembangan modul. Analisis dimulai dengan analisis ujung depan yang dilakukan dengan pemberian angket kepada guru untuk mengetahui bagaimana proses pembelajaran yang dilakukan selama ini. Selanjutnya analisis siswa yang dilakukan dengan pemberian angket kepada peserta didik kelas XI MA untuk mengetahui kebutuhan belajarnya. Analisis berlanjut pada analisis tugas, konsep, dan perumusan tujuan pembelajaran. Berdasarkan beberapa analisis tersebut maka peneliti dapat menentukan batasan materi dengan kebutuhan peserta didik.

Tahap perancangan atau design modul meliputi beberapa langkah, yaitu: menyiapkan buku referensi yang berkaitan dengan sistem reproduksi dan kaitannya dengan Islam, menyusun peta kebutuhan modul, penyusunan desain modul, serat penyusunan desain instrumen penilaian. tahap ini dilakukan untuk membuat modul atau buku ajar sesuai dengan kerangka isi hasil analisis kurikulum dan materi (Mulyatiningsih, diakses 22 Juni 2016).

Tahapan selanjutnya adalah develop, tahap ini berupa validasi modul oleh ahli/pakar materi pada mata pelajaran yang sama, ahli media pembelajaran dan penilaian oleh guru biologi di MA Darul Falah. Setelah dinilai pada tahap pertama, selanjutnya peneliti melakuakn revisi modul berdasarkan masukan dari para pakar pada saat validasi.

Uji coba dilanjutkan dengan uji lapangan terbatas dalam pembelajaran di luar kelas dengan melakukan uji keterbacaan. Subjek penelitiannya adalah enam peserta didik kelas XI MA tahun ajaran 2016/2017 berjumlah enam orang.

Uji coba lapangan luas dengan hasil akhir modul dalam pembelajaran di kelas XI sesuai situasi nyata yang akan dihadapi, dengan subjek penelitian 15 peserta didik kelas eksperimen dan 15 peserta didik kelas kontrol di MA Darul Falah. Pengajuan dilakukan setelah guru biologi menyampaikan materi sistem reproduksi. Peneliti melakukan uji selama dua kali pertemuan, dimana pertemuan pertama akan dilakukan pretest dan penyampaian kegiatan belajar satu dan dua yang ada di dalam modul, sedangkan pertemuan kedua akan dilakukan kegiatan belajar tiga, posttest dan pemberian angket penilaian peserta didik terhadap modul. Sementara tahapan disseminate tidak dilakukan peneliti karena penelitian hanya dibatasi sampai develop.

Teknik pengumpulan data menggunakan teknik tes, angket dan dokumentasi. Tes dilakukan dengan cara memberikan pre-test dan post-test. Pada penelitian ini menggunakan angket tertutup dimana angket disusun menggunakan pilihan jawaban lengkap sehingga pengisi hanya tinggal memberi tanda pada jawaban yang dipilih (Arikunto, 2009). Dokumentasi merupakan catatan peristiwa yang sudah berlalu. Baik penilaian ahli materi, ahli media, guru maupun peserta didik, penilaian menggunakan acuan berupa skala bertingkat. 
Tabel 1. Kriteria Penilaian

\begin{tabular}{cc}
\hline Skala & Kategori \\
\hline 5 & Sangat Baik \\
4 & Baik \\
3 & Cukup \\
2 & Kurang Baik \\
1 & Sangat Kurang \\
\hline
\end{tabular}

Selanjutnya dari hasil penilaian tersebut, data hasil kelayakan modul dianalisis dengan deskriptif presentase, dengan rumus:

$$
\%=\frac{n}{N} \times 100 \%
$$

Keterangan :

$$
\begin{gathered}
\%=\begin{array}{c}
\text { Persentase skor } \\
n=\Sigma \text { skor } \\
N=\Sigma \text { skor total }
\end{array}
\end{gathered}
$$

Keterangan penentuan jenjang kualifikasi kriteria kelayakan ditentukan dalam tabel 2 yang diadaptasi dari Akbar (2013).

Tabel 2. Kriteria Kelayakan

\begin{tabular}{cc}
\hline Persentase & Kategori \\
\hline $81-100 \%$ & Sangat Layak \\
$61-80 \%$ & Layak \\
$41-60 \%$ & Kurang Layak \\
$21-50 \%$ & Tidak Layak \\
$0-20 \%$ & Sangat Tidak Layak \\
\hline
\end{tabular}

Modul dikatakan layak digunakan dalam pembelajaran apabila: hasil penilaian kelayakan modul oleh ahli media maupun ahli materi menunjukkan bahwa modul tersebut layak untuk digunakan dalam pembelajaran. Hasil tanggapan peserta didik menunjukkan bahwa modul layak untuk digunakan (Mulyasa, 2010).

Penilaian pada aspek kognitif peserta didik dapat dilihat dari hasil belajar peserta didik tersebut. Keberhasilan yang ingin dilihat yaitu seberapa besar pemahaman peserta didik terhadap materi. Lebih jelasnya dapat menggunakan rumus berikut ini:

$$
\text { Skor }=\frac{\text { jumlah skor seluruh siswa }}{\text { Skor maksimal }} \times 100 \%
$$

Pada penelitian ini target pada aspek kognitif terhadap peserta didik adalah $75 \%$, maka modul dapat dikatakan layak terhadap hasil belajar peserta didik minimal mencapai 75\% (Purwanto, 2010). Sedangkan untuk menentukan persentase ketuntasan secara klasikal digunakan rumus:

$$
\mathrm{P}=\frac{\sum n i}{\sum n} x 100
$$

Keterangan :

$\mathrm{P} \quad=$ Ketuntasan belajar secara klasikal

$\Sigma \mathrm{ni} \quad=$ Jumlah peserta didik yang tuntas secara individual

$\Sigma \mathrm{n}=$ Jumlah total peserta didik (Trianto, 2010) 


\section{HASIL PENELITIAN DAN PEMBAHASAN}

Penelitian dimulai dari tahapan define, yaitu dengan melakukan analisis ujung depan yang dilakukan dengan memberikan angket kepada guru, serta analisis siswa yang dilakukan dengan memberikan angket kepada siswa. Analisis dilanjutkan dengan analisis tugas, analisis konsep, dan perumusan tujuan pembelajaran. Analisis tersebut mendapatkan hasil bahwa kondisi pembelajaran di madrasah yang ditelliti dominan mennggunakan model ceramah meskipun sudah divariasi dengan diskusi dan tanya jawab. Kondisi sumber belajar masih minim variasinya. Madarasah yang notabene pendidikannya berdasarkan nilai Islam, belum mempunyai sumber belajar biologi yang dikaitkan dengan nilai Islam. Peserta didik juga setuju dengan pengembangan modul bernilai Islam, karena mereka mengharapkan adanya tambahan referensi untuk menunjang proses belajar mandiri yang dikaitkan dengan nilai Islam.

Berdasarkan hasil observasi tersebut, maka peneliti melakukan pengembangan sumber belajar dengan mengembangkan modul yang diintegrasikan dengan nilai Islam. Modul yang dikembangkan tidak hanya menonjolkan aspek integrasinya pada nilai Islam, tetapi juga bersifat mudah dipahami, menarik, inovatif serta menimbulkan semangat peserta didik dalam belajar khususnya materi Sistem Reproduksi pada Manusia.

Berdasarkan pendefinisian masalah di atas, akhirnya modul di design dengan menentukan tes acuan patokan, penentuan media dan juga pemilihan format. Peneliti juga membuat instrumen dan produk rancangan awal (prototipe) yang kemudian di uji pada ahli validator, yang meliputi ahli materi dan ahli media serta guru Biologi yang mengajar di MA.

Format modul yang digunakan peneliti dalam menyusun modul adalah format penulisan modul menurut Surahman (2010:2), yang telah disesuaikan dengan kebutuhan penulis. Formatnya yaitu, judul modul, petunjuk umum, meliputi (KD, pokok bahasan, indikator, referensi, lembar kegiatan pembelajaran, evaluasi), materi modul, serta evaluasi akhir kegiatan (Prastowo, 2015)

Berikut ini adalah hasil validasi ahli materi dan juga ahli media dalam menilai modul yang dikembangkan oleh peneliti.

Tabel 1. Hasil Validasi Ahli Materi

\begin{tabular}{clc}
\hline No & \multicolumn{1}{c}{ Aspek Evaluasi } & Skor \\
\hline 1 & Kesesuaian materi & 12 \\
2 & Keakuratan materi & 28 \\
3 & Pendukung materi pembelajaran & 26 \\
4 & Kemutakhiran materi & 11 \\
5 & Teknik penyajian & 12 \\
6 & Pendukung penyajian materi & 43 \\
7 & Sesuai dengan perkembangan peserta didik & 8 \\
8 & Komunikatif & 8 \\
9 & Dialogis dan Interaktif & 16 \\
10 & Kesesuaian dengan kaidah Bahasa Indonesia & 8 \\
11 & Koherensi dan keruntutan alur berpikir & 12 \\
12 & Penggunaan istilah dan simbol/lambing & 8 \\
13 & Penyajian nilai Islam & 8 \\
14 & Kesesuaian nilai Islam & 13 \\
15 & Sesuai dengan perkembangan peserta didik & 8 \\
\hline
\end{tabular}




\begin{tabular}{ccc}
\hline No & Aspek Evaluasi & Skor \\
\hline & Jumlah & 221 \\
\hline & Presentase & $83,39 \%$ \\
\hline
\end{tabular}

Tabel 2. Hasil Validasi Ahli Media/Grafika

\begin{tabular}{clc}
\hline No & \multicolumn{1}{c}{ Aspek Evaluasi } & Skor \\
\hline 1 & Ukuran fisik modul & 8 \\
2 & Tata letak kulit modul & 17 \\
3 & Huruf yang digunakan menarik dan mudah dibaca & 20 \\
4 & llustrasi sampul modul & 9 \\
5 & Konsistensi tata letak & 13 \\
6 & Unsur tata letak harmonis & 9 \\
7 & Unsur tata letak lengkap & 8 \\
8 & Tata letak mempercepat pemahaman & 8 \\
9 & Tipografi isi buku sederhana & 12 \\
10 & Tipografi mudah dibaca & 12 \\
11 & Tipografi isi buku memudahkan pemahaman & 4 \\
12 & llustrasi isi & 17 \\
\hline & & 137 \\
\hline & Jumlah
\end{tabular}

Selain divalidasi oleh ahli, modul juga diberikan kepada guru biologi untuk mengetahui tanggapan guru tentang modul yang telah dikembangkan, apakah sudah layak digunakan dalam pembelajaran atau perlu direvisi kembali.

Tabel 3. Hasil Tanggapan Guru Biologi

\begin{tabular}{|c|c|c|}
\hline No & Aspek Evaluasi & Skor \\
\hline 1 & Kejelasan teks & 4 \\
\hline 2 & Kejelasan gambar & 13 \\
\hline 3 & Kemenarikan gambar & 4 \\
\hline 4 & Kesesuaian gambar dengan materi & 4 \\
\hline 5 & Penyajian materi & 21 \\
\hline 6 & Kesesuaian soal dengan materi & 4 \\
\hline 7 & Kejelasan kalimat & 4 \\
\hline 8 & Kemudahan belajar & 11 \\
\hline \multirow[t]{3}{*}{9} & Kaitan dengan nilai Islam & 17 \\
\hline & Jumlah & 82 \\
\hline & Presentase & $82 \%$ \\
\hline
\end{tabular}

Berdasarkan tabel 1, 2 dan 3 hasil uji kelayakan terhadap rancangan model awal modul yang dikembangkan terdapat beberapa masukan, antara lain: ukuran gambar perlu diperjelas, gambar hasil tangkapan layar masih buram, terdapat beberapa kesalahan dalam penulisan kata dan penyusunan kalimat, serta penambahan beberapa konsep Islam untuk melengkapi materi. Grafik hasil uji kelayakan dapat diamati pada gambar 1 berikut: 


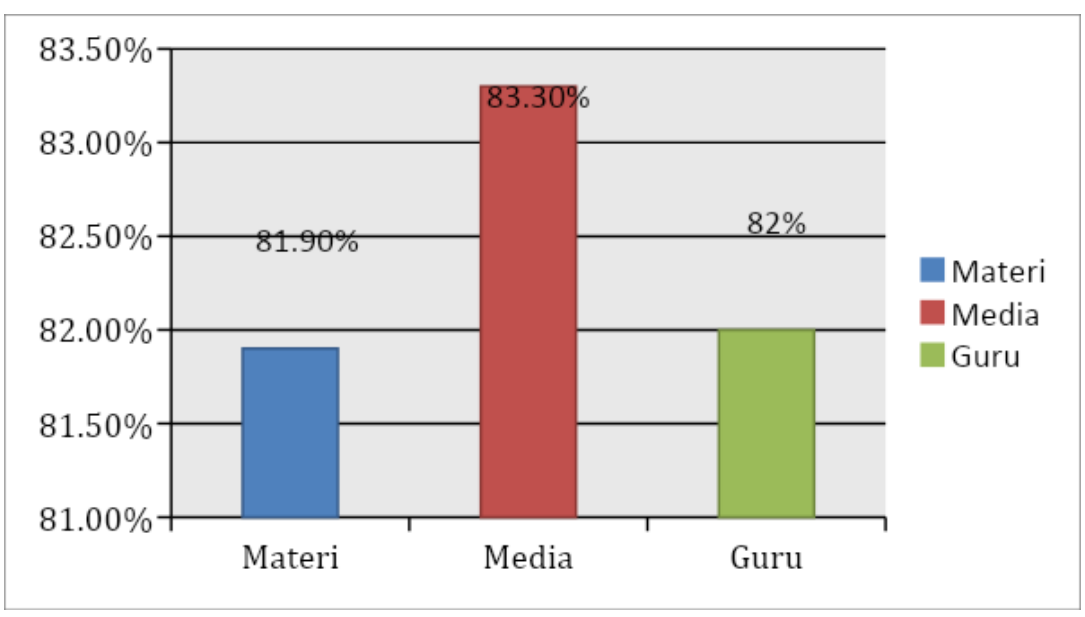

Gambar 1. Grafik Hasil Uji Kelayakan Ahli dan Guru

Hasil uji kelayakan mendapatkan penilaian dari ahli materi sebesar $81,9 \%$ dan dari ahli media sebesar $83,3 \%$. Sementara hasil penilaian dari pihak guru adalah sebesar $82 \%$. Itu artinya modul yang dikembangkan sudah masuk dalam kriteria sangat layak dan bisa digunakan pada uji selanjutnya.

Tahapan uji pada kelas kecil masing-masing siswa diberikan angket yang berisi pertanyaan-pertanyaan mengenai kesesuaian media terhadap materi, aspek tampilan, aspek penyajian materi, dan manfaat modul.

Tabel 4. Hasil Tanggapan Peserta Didik Kelas Kecil

\begin{tabular}{ccccc}
\hline Aspek & No. & Skor & Presentase & Kriteria \\
\hline \multirow{5}{*}{ Tampilan } & 1 & 26 & $86 \%$ & Sangat layak \\
& 2 & 25 & $83 \%$ & Sangat layak \\
& 3 & 21 & $70 \%$ & Layak \\
& 4 & 24 & $80 \%$ & Layak \\
& 5 & 25 & $83 \%$ & Sangat layak \\
& 6 & 26 & $86 \%$ & Sangat layak \\
\hline \multirow{6}{*}{ Penyajian Materi } & 7 & 20 & $66 \%$ & Layak \\
& 8 & 21 & $70 \%$ & Layak \\
& 9 & 23 & $76 \%$ & Layak \\
& 10 & 25 & $83 \%$ & Sangat layak \\
& 11 & 22 & $73 \%$ & Layak \\
& 12 & 22 & $73 \%$ & Layak \\
& 13 & 23 & $76 \%$ & Layak \\
& 14 & 21 & $70 \%$ & Layak \\
& 15 & 23 & $76 \%$ & Layak \\
& 16 & 26 & $86 \%$ & Sangat layak \\
\hline \multirow{6}{*}{ Manfaat } & 17 & 20 & $66 \%$ & Layak \\
& 18 & 22 & $73 \%$ & Layak \\
& 19 & 21 & $70 \%$ & Layak \\
& 20 & 21 & $70 \%$ & Layak \\
& 21 & 21 & $70 \%$ & Sangat layak \\
& 22 & 28 & $93 \%$ & Sangat layak \\
& 23 & 29 & $96 \%$ & Sangat layak \\
& 24 & 28 & $93 \%$ & Sangat layak \\
\hline Rata-rata & 25 & 27 & $90 \%$ & Layak \\
\hline
\end{tabular}


Berdasarkan tabel tersebut dapat diketahui bahwa tanggapan peserta didik pada kelas kecil adalah sebesar $78 \%$, artinya modul yang dikembangkan masuk dalam kategori layak. Grafik hasil tanggapan peserta didik pada kelas besar dapat dilihat pada grafik berikut:

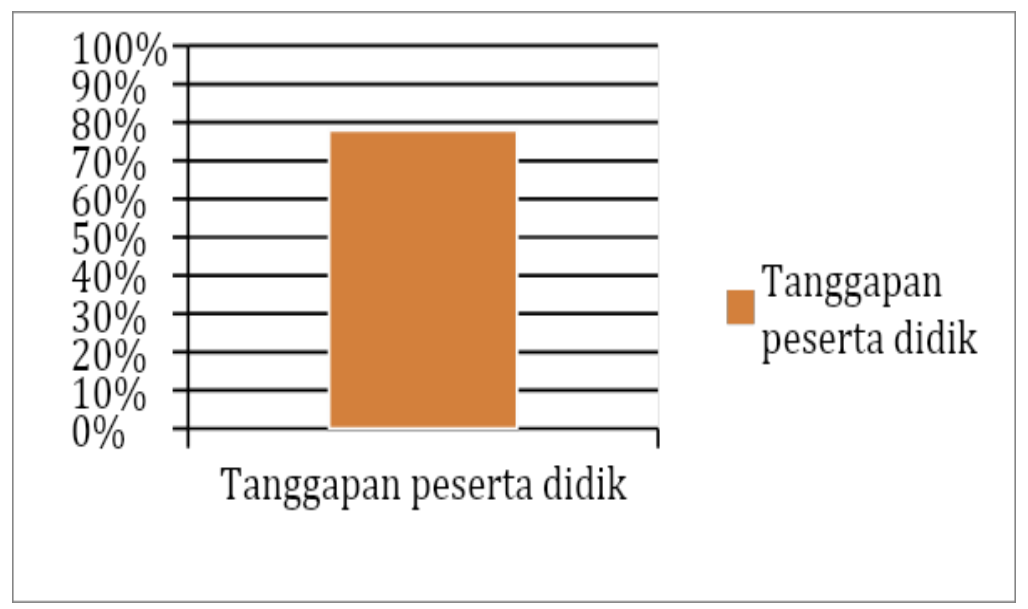

\section{Gambar 2. Grafik Hasil Tanggapan Kelas Kecil}

Berdasarkan tanggapan peserta didik pada uji skala kecil, ada beberapa hal yang harus diperbaiki oleh peneliti, yaitu perbaiakan resolusi gambar, serta penulisan keterangan gambar agar lebih diperjelas.

Setelah direvisi, dilakukan uji lapangan lebih luas pada kelas besar yaitu terdiri atas 15 peserta didik untuk kelas eksperimen dan 15 peserta didik untuk kelas kontrol. Penelitian ini membutuhkan adanya kelas kontrol dan eksperimen. Penelitian dengan perlakuan satu kelompok saja tanpa adanya kelompok pembanding merupakan jenis bad example, artinya penelitian tersebut tidak baik karena tidak bisa menggambarkan bagaimana kondisi kelompok lain yang tidak diberikan perlakuan tersebut (Thiagarajan, 1974).

Perlakuan yang diberikan pada kelas eksperimen adalah dengan memberikan soal pretest pada peserta didik sebelum pembelajaran, kemudian guru memberikan materi sistem reproduksi menggunakan modul berniai Islam, setelah itu guru memberikan soal posttest untuk mengetahui bagaimana pengaruh penggunaan modul selama proses pembelajaran, di akhir perlakuan peserta didik dimintai tanggapan atas modul yang dipelajari.

Disisi lain, kelompok kelas kontrol hanya diberikan soal pretest dan posttest tanpa memberikan materi sistem reproduksi menggunakan modul bernilai Islam. Berikut adalah hasil uji lapangan lebih luas pengembangan modul bernilai Islam:

Tabel 5. Hasil Pre-test dan Post-test kelas kontrol

\begin{tabular}{ccccc}
\hline $\begin{array}{c}\text { Rata-rata } \\
\text { Pretest }\end{array}$ & $\begin{array}{c}\text { Rata-rata } \\
\text { Posttest }\end{array}$ & $\begin{array}{c}\text { Jumlah peserta didik } \\
\text { yang tuntas }\end{array}$ & Ketuntasan klasikal & Kriteria \\
\hline 49,3 & 60,3 & 2 & $13 \%$ & Tidak layak \\
\hline
\end{tabular}

Tabel 6. Hasil Pre-test dan Post-test kelas eksperimen

\begin{tabular}{ccccc}
\hline $\begin{array}{c}\text { Rata-rata } \\
\text { Pretest }\end{array}$ & $\begin{array}{c}\text { Rata-rata } \\
\text { Posttest }\end{array}$ & $\begin{array}{c}\text { Jumlah peserta didik } \\
\text { yang tuntas }\end{array}$ & Ketuntasan klasikal & Kriteria \\
\hline 48,6 & 83 & 14 & $93 \%$ & Sangat layak \\
\hline
\end{tabular}


Berdasarkan perbandingan hasil Pre-test dan Post-test baik kelas kontrol maupun kelas eksperimen, diketahui bahwa pada kelas kontrol hanya 2 peserta didik saja yang tuntas, atau ketuntasan klasikalnya hanya sebesar $13 \%$. Sementara pada kelas eksperimen bisa mencapai $93 \%$ atau sebanyak 14 peserta didik yang tuntas, dari 15 peserta didik dalam kelompok tersebut.

Grafik hasil perbandingan pre-test dan post-test antara kelas kontrol dengan eksperimen dapat diamati pada gambar 4.27:

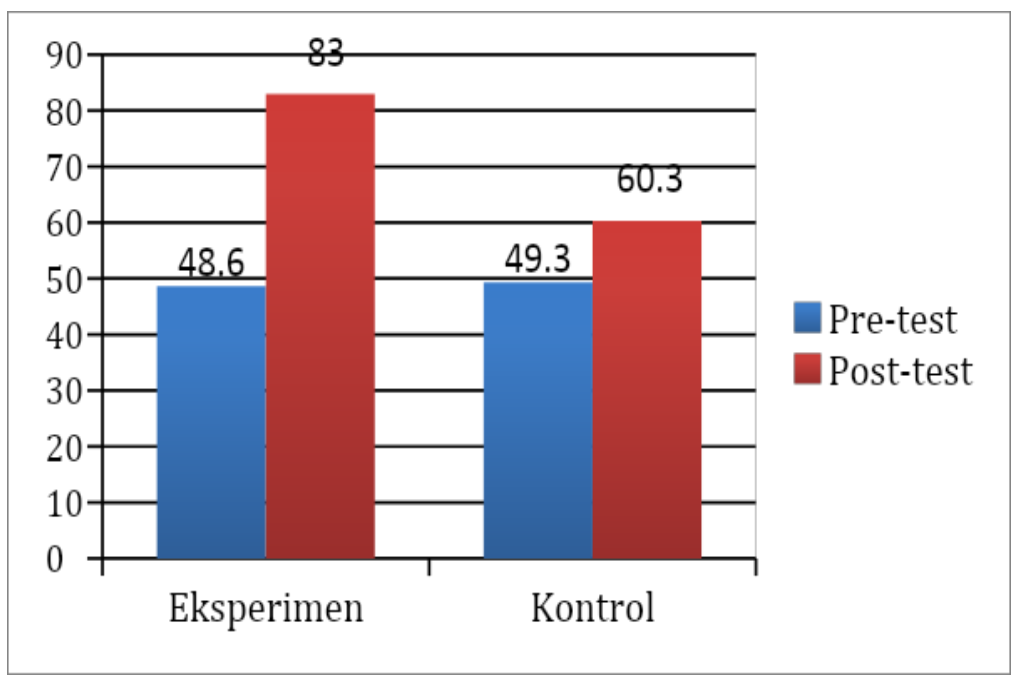

Gambar 3. Grafik Perbandingan Pre-Test dan Post-Test Kelas Kontrol dengan Eksperimen

Siswa yang belum tuntas disebabkan oleh beberapa faktor, yaitu motivasi yang mempengaruhi tingkah laku siswa di kelas dan yang mempengaruhi keberhasilan dalam situasi belajar, persepsi siswa terhadap dirinya sendiri juga mempengaruhi hasil belajar siswa, selain itu kecemasan siswa dalam mengerjakan post-test dapat mempengaruhi hasil belajarnya (Soemanto, 1990).

Penilaian kelayakan modul juga dilihat dari hasil tanggapan peserta didik kelas besar.

Tabel 7. Hasil Tanggapan Peserta Didik Kelas Besar

\begin{tabular}{|c|c|c|c|c|}
\hline Aspek & No. & Skor & Presentase & Kriteria \\
\hline \multirow{6}{*}{ Tampilan } & 1 & 65 & $86,7 \%$ & Sangat layak \\
\hline & 2 & 62 & $82,7 \%$ & Sangat layak \\
\hline & 3 & 57 & $76 \%$ & Layak \\
\hline & 4 & 62 & $82,7 \%$ & Sangat layak \\
\hline & 5 & 61 & $81,3 \%$ & Sangat layak \\
\hline & 6 & 64 & $85,3 \%$ & Sangat layak \\
\hline \multirow{10}{*}{ Penyajian Materi } & 7 & 53 & $70,7 \%$ & Layak \\
\hline & 8 & 56 & $74,7 \%$ & Layak \\
\hline & 9 & 60 & $80 \%$ & Layak \\
\hline & 10 & 63 & $84 \%$ & Sangat layak \\
\hline & 11 & 56 & $74.7 \%$ & Layak \\
\hline & 12 & 59 & $78,7 \%$ & Layak \\
\hline & 13 & 59 & $78,7 \%$ & Layak \\
\hline & 14 & 57 & $76 \%$ & Layak \\
\hline & 15 & 54 & $72 \%$ & Layak \\
\hline & 16 & 66 & $88 \%$ & Sangat layak \\
\hline
\end{tabular}




\begin{tabular}{ccccc}
\hline Aspek & No. & Skor & Presentase & Kriteria \\
\hline \multirow{6}{*}{ Manfaat } & 17 & 55 & $73,3 \%$ & Layak \\
& 18 & 59 & $78,7 \%$ & Layak \\
& 19 & 57 & $76 \%$ & Layak \\
& 20 & 57 & $76 \%$ & Layak \\
& 21 & 55 & $73,3 \%$ & Layak \\
& 22 & 67 & $89,3 \%$ & Sangat layak \\
& 23 & 70 & $93,3 \%$ & Sangat layak \\
& 24 & 70 & $93,3 \%$ & Sangat layak \\
& 25 & 68 & $90,7 \%$ & Sangat layak \\
\hline \multicolumn{6}{c}{ Jumlah } & & 1512 & & \\
\hline Rata-rata & & & &
\end{tabular}

Grafik hasil tanggapan peserta didik pada kelas besar dapat diamati pada gambar 4.28 berikut:

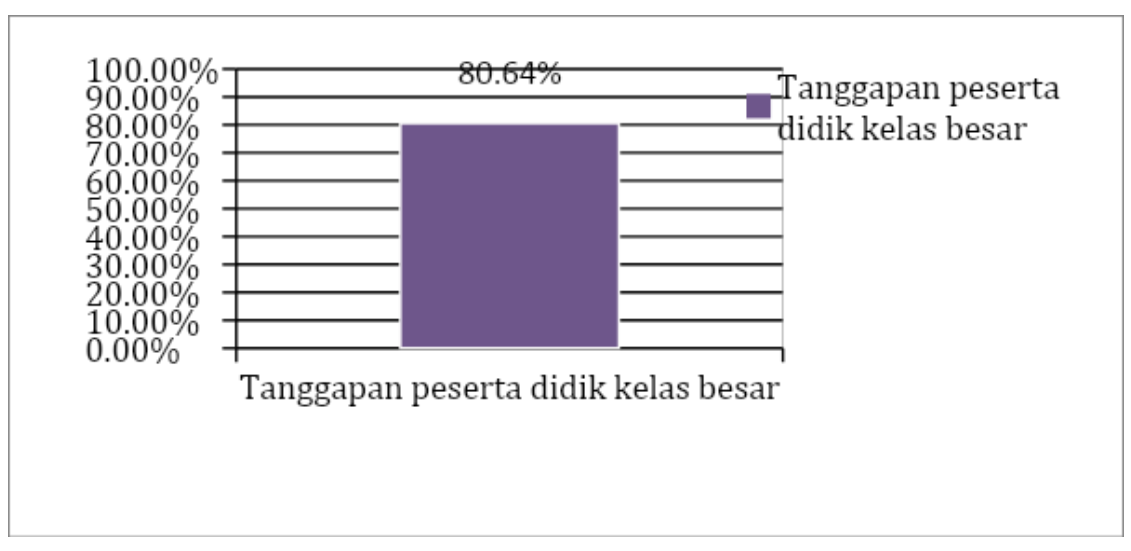

Gambar 4. Grafik Hasil Tanggapan Peserta Didik pada Kelas Besar

Hasil tanggapan pada kelas eksperimen menunjukkan nilai sebesar $80,64 \%$, artinya modul tersebut masuk dalam kategori layak. Hal itu dilihat dari respon setuju hingga sangat setuju yang diberikan peserta didik terhadap modul baik untuk aspek tampilan, penyajian materi dan manfaat. Peserta didik merasa lebih mudah dan lebih tertarik dalam belajar Biologi. Selain itu, yang menjadikan modul ini diminati oleh peserta didik adalah karena materi modul yang mengandung nilai Islam. Beberapa peserta didik dalam tanggapannya mengungkapkan bahwa modul tersebut sangat bagus dan sangat bermanfaat bagi usia remaja karena berisi nilai-nilai Islam.

\section{SIMPULAN DAN SARAN}

Berdasarkan hasil penelitian dan pengembangan yang dilakukan peneliti, maka dapat diambil kesimpulan bahwa produk hasil pengembangan yang berupa modul biologi bernilai Islam yang dikembangkan dengan metode 4-D (define, design, develop, and disseminate) layak digunakan dalam pembelajaran di MA Darul Falah Sirahan Pati. Hal tersebut berdasarkan pada penilaian kualitas modul oleh ahli materi dan ahli media mencapai presentase sebesar $81,9 \%$ untuk materi dan $83,3 \%$ untuk media serta tanggapan guru sebesar $82 \%$.

Tingkat keefektifan peserta didik mempunyai kriteria sangat tinggi, dengan tingkat ketuntasan klasikal pada kelas eksperimen mencapai 93\% sedangkan pada kelas kontrol hanya $13 \%$. Adapun hasil untuk presentase tanggapan peserta didik 
pada kelas kecil adalah $78 \%$ dengan kriteria layak, dan tanggapan peserta didik pada kelas besar sebesar $80,64 \%$ dengan kriteria sangat layak.

\section{RUJUKAN}

Akbar, Sa'dun. (2013). Instrumen Perangkat Pembelajaran. Bandung: Remaja Rosdakarya.

Arikunto, S. (2009). Dasar-dasar Evaluasi Pendidikan. Jakarta: Bumi Aksara.

Dharma, S. (2008). Penulisan Modul. Direktorat Tenaga Kependidikan , 3-5.

Handoko, A., Sajidan, S., \& Maridi, M. (2016). Pengembangan Modul Biologi Berbasis Discovery Learning (Part Of Inquiry Spectrum Learning-Wenning) Pada Materi Bioteknologi Kelas Xii Ipa Di Sma Negeri 1 Magelang Tahun Ajaran 2014/2015. Inkuiri, 5(3), 144-154.

Mulyasa. E,. (2010). Kurikulum Tingkat Satuan Pendidikan. Bandung : Remaja Rosdakarya.

Mulyatiningsih, Endang. Pengembangan Model pembelajaran, http.staff.uny.ac.id, diakses 22 Juni 2016.

Rohani, A. (1997). Media Instruksional Edukatif. Jakarta: Rineka Cipta.

Soemanto, Wasty. (1990). Psikologi Pendidikan, Jakarta: Rineka Cipta,

Prastowo, A. (2012). Pengembangan Sumber Belajar. Yogyakarta: Pedagogia.

Prastowo, A. (2012). Pengembangan Sumber Belajar. Yogyakarta: Pedagogia.

Thiagarajan, S,. Dorothy S. Semmel, dan Melvyn I. Semmel. (1974). Instructional Development for Training Teachers of Exceptional Children A Sourcebook. Indiana: Indiana University Bloomington.

Trianto. (2010). Mendesain Model Pembelajaran Inovatif - Progresif. Jakarta: Kencana.

Udaibah, W. (2013). Pengembangan Modul Kimia Anorganik Terintegrasi Pendidikan Karakter pada Materi Kimia Koordinasi Tadris Kimia IAIN Walisongo Semarang. Semarang: IAIN Walisongo. 